\title{
Medium and large-sized mammals of the Reserva Ecológica de Guapiaçú, Cachoeiras de Macacu, RJ
}

\author{
Israel Dias de Carvalho ${ }^{1,3}$, Rildo de Oliveira ${ }^{2}$ \& Alexandra dos Santos Pires ${ }^{I}$ \\ ${ }^{1}$ Laboratório de Ecologia e Conservação de Florestas, Departamento de Ciências Ambientais, Instituto de \\ Florestas, Universidade Federal Rural do Rio de Janeiro, Rio de Janeiro, RJ, Brazil. \\ ${ }^{2}$ Reserva Ecológica de Guapiaçú, Rio de Janeiro, RJ, Brazil. \\ ${ }^{3}$ Corresponding author: Israel Dias de Carvalho, e-mail: israelcarvalho31@gmail.com
}

CARVAlHO, I. D., OLIVEIRA, R., PIRES, A. S. Medium and large-sized mammals of the Reserva Ecológica de Guapiaçú, Cachoeiras de Macacu, RJ.Biota Neotropica. 14(3): e20140074.http://dx.doi.org/ 10.1590/1676-06032014007414

\begin{abstract}
Medium and large-sized terrestrial mammals develop important functions in ecosystems maintenance. However, this group is the most vulnerable to local extinctions, through habitat loss or hunting. This study inventoried the community of medium and large mammals in the Reserva Ecológica de Guapiaçú (REGUA), Cachoeiras de Macacu, RJ, providing data on species composition, richness and abundance. Species were registered through the use of camera traps, sign survey and visual encounters on pre-existing trails and roads. The study was conducted from January to October 2012, with each month considered as a sample unit. An effort of 1568 cameras-day and $120 \mathrm{~km}$ traveled, resulted on 302 records of 22 species of medium and large-sized mammals, belonging to eight orders. This value corresponds to more than three-quarters of the richness described from this group in the Atlantic Forest of Rio de Janeiro state. Five species are under some level of regional, national or global threat. Three game species, Pecari tajacu, Cuniculus paca and Dasyprocta leporina were abundant in the area. The observed richness was comparable to that found in other studies conducted in rain forests. Thus, for its high number of species, including those under some degree of threat, we conclude that REGUA is an important area to mammal conservation, especially in the Atlantic Forest of Rio de Janeiro state.
\end{abstract}

Keywords: Mammal community, endangered species, camera traps, sign survey, Atlantic Forest.

CARvalho, I. D., OLIVEIRA, R., PIRES, A. S. Mamíferos de médio e grande porte da Reserva Ecológica de Guapiaçú, Cachoeiras de Macacu, RJ. Biota Neotropica. 14(3): e20140074. http://dx.doi. org/10.1590/1676-06032014007414

Resumo: Mamíferos de médio e grande porte desempenham funções importantes para a manutenção dos ecossistemas. Porém, esse grupo é um dos mais vulneráveis a extinções locais, seja pela perda de hábitat ou pela caça. Neste estudo foi inventariada a comunidade de médios e grandes mamíferos na Reserva Ecológica de Guapiaçú (REGUA), Cachoeiras de Macacu, RJ, sendo descritos dados de composição, riqueza e abundância. As espécies foram registradas através do uso de armadilhas fotográficas, busca por vestígios e visualizações diretas em trilhas e estradas pré-existentes. O estudo foi realizado de janeiro a outubro de 2012, sendo cada mês considerado uma unidade amostral. A partir de um esforço de 1568 câmeras-dia e de $120 \mathrm{~km}$ caminhados, obtivemos 302 registros de 22 espécies de mamíferos de médio e grande porte, pertencentes a oito Ordens. Esse valor corresponde a mais que três quartos da riqueza de espécies descrita para esse grupo na Mata Atlântica do estado do Rio de Janeiro. Cinco espécies encontram-se sob algum nível de ameaça regional, nacional ou global. Três espécies cinegéticas, Pecari tajacu, Cuniculus paca e Dasyprocta leporina foram abundantes na área. A riqueza observada foi comparável à encontrada em outros estudos realizados em florestas ombrófilas densas. Assim, por seu elevado número de espécies, incluindo aquelas sob algum grau de ameaça, concluímos que a REGUA é um lugar de destaque para a conservação da biodiversidade de mamíferos, especialmente na Mata Atlântica do estado do Rio de Janeiro.

Palavras-chave: Comunidade de mamíferos, espécies ameaçadas, armadilhas fotográficas, busca por vestígios, Mata Atlântica. 


\section{Introduction}

Medium and large-sized terrestrial mammals develop important functions in ecosystems maintenance. These animals affects plant population dynamics through herbivory and physical damage (e.g. Dirzo \& Miranda 1990, Keuroghlian \& Eaton 2009, Beck et al. 2013), and also through their role as seed dispersers and predators (e.g. Asquith et al. 1997, Asquith et al. 1999, Galetti et al. 2006, Donatti et al. 2009, Kuprewicz 2013) contributing to plant local diversity. Acting as animal predators they also regulate herbivore populations (e.g. Terborgh 1988, Sinclair et al. 2003) affecting prey activity patterns (Lima \& Dill 1990), and reducing competition by resources favoring species co-ocorrence (Miller et al. 2001). In this way, these animals favor forest complexity and heterogeneity (e.g. Miller et al. 2001). Besides that, they contribute also to the conservation of other species acting as umbrella species (e.g. Noss et al. 1996) especially by their large area requirements. These animals are also among the main flagship species (e.g. Mittermeier 1986), due to their charismatic attributes. Due to its ability to move inside habitat mosaics, these mammals have been used also as landscape species, contributing to conservation planning in larger scales (Bani et al. 2002, Sanderson et al. 2002a, Crouzeilles et al. 2010).

In spite of their importance, these animals are among the most vulnerable to local extinction following anthropogenic disturbance, due to their naturally low population densities (e.g. Cullen et al. 2005, Soisalo \& Cavalcanti 2006), their large area requirements (Sanderson et al. 2002b, Cullen et al. 2005) and also because they are preferential targets to hunters (Redford 1992, Peres 1996, Cullen et al. 2001, Travassos 2011). These factors has conducted to the loss of these animals in tropical forests, promoting profound transformations in forest dynamics and threaten the maintenance of these ecosystems (Stoner et al. 2007, Jorge et al. 2013, Kurten 2013, Harrison et al. 2013).

Due to this rugged relief and edaphic characteristics, which promotes a variety of ecological conditions, the Atlantic Forest at Rio de Janeiro state harbor a high biodiversity (e.g. Bergallo et al. 2000). The unrivalled numbers of endemic species and a relentless process of post-colonial deforestation (Dean 1996) make this forest an important region inside this Brazilian hotspot (Myers et al. 2000). Actually, the forest cover only $19.6 \%$ of the state area (Fundação SOS Mata Atlântica \& INPE 2011) in a fragmented distribution (Ribeiro et al. 2009), contributing to biodiversity loss through the reduction of suitable areas to mammal persistence, especially for the larger species (Cardillo \& Bromhan 2001, Kinnaird et al. 2003, Ewers \& Didham 2006). Besides that, fragmentation facilitates the access of hunters (Peres 2000), increasing the negative pressures over the populations of these animals (Chiarello 2000, Cullen et al. 2001). In this scenario, large ( $>100 \mathrm{ha})$, protected remnants are responsible to maintain the diversity of medium and largesized mammals (Canale et al. 2012).

In spite of their importance and vulnerability, few studies had been carried out with this mammal group in the Atlantic Forest. The difficulties related to the study of these animals are due to their furtive habits (Reis et al. 2006, Barea-Azcón et al. 2007), and habitat requirements (Sanderson et al. 2002b, BareaAzcón et al. 2007). Recently, the use of new tracking technologies as camera traps (e.g. Karanth \& Nichols 1998, Santos-Filho \& Silva 2002, Galetti et al. 2006, Srbek-Araújo \&
Chiarello 2007, Goulart et al. 2009, Carvalho et al. 2013), and their combined use with other sampling techniques as footprint traps, linear transects and sign surveys (Passamani et al. 2005, Negrão \& Valladares-Pádua 2006, Spínola 2008, Modesto et al. 2008a, Silva \& Passamani, 2009, Espartosa et al. 2011, Delciellos et al. 2012) have favored studies with this group. However, due to be a recent approach, several areas still represents knowledge gaps for this group, especially in the Rio de Janeiro state (Cunha 2004, Modesto et al. 2008a,b, Delciellos et al. 2012). Inventories of this group are still needed to a better understanding of the regional biodiversity and its ecological patterns. These studies are of fundamental importance to verify the conservation status of the species and to develop monitoring and management and strategies (NorthonGriffiths 1978, Boddicker et al. 2002, Gaidet-Drapier et al. 2006). From these information is possible to define priority areas for conservation, establish minimum areas for reserves and to understand the main treats, consolidating the conservation strategies in these areas.

This study aim to characterize the assemblage of medium and large sized mammals of a preserved area of the Atlantic Forest, the Reserva Ecológica de Guapiaçú (REGUA), situated at Cachoeiras de Macacu, RJ. More specifically, were assessed the species composition, richness and species abundance in the area.

\section{Material and Methods}

\section{Study area}

The Reserva Ecológica de Guapiaçú (REGUA, 22²2'12”' S $-22^{\circ} 27^{\prime} 18^{\prime \prime} \mathrm{S}$ and $42^{\circ} 42^{\prime} 25^{\prime \prime} \mathrm{O}-42^{\circ} 49^{\prime} 19^{\prime \prime} \mathrm{O}$ ) is a private area, covering 7300 ha. The vegetation is the rain forest, covering montane, sub-montane and lowland areas (Oliveira-Filho \& Fontes 2000). In the last, most part of the vegetation is in initial successional stages due to the recent history of anthropogenic disturbance. The most representative botanical families in the area are Fabaceae, Rubiaceae, Myrtaceae, Lauraceae, Meliaceae, Euphorbiaceae, Sapindaceaea, Melastomataceae, Annonaceae and Sapotaceae (Azevedo 2012). The climate is classified as Am according to Köppen (Peel et al. 2007), with annual mean temperature of $22.4{ }^{\circ} \mathrm{C}$ and maximum temperatures occurring in January and February and minimum in July. The annual rainfall is $2095 \mathrm{~mm}$; December and January are the rainy months and June and July the driest ones. The altitude ranges from $20 \mathrm{~m}$ to ca. $2000 \mathrm{~m}$. The area overlaps with the Parque Estadual dos Três Picos which is the largest state conservation unit from Rio de Janeiro, covering 58.790 ha (INEA 2013). About $94.8 \%$ of REGUA is covered by forest and the remaining areas include swamp, pastureland, and agriculture.

\section{Data collection}

The study was carried out from January to October 2012, and each month was considered a sample event. The species was registered through the combined use of camera traps, sign surveys and visual encounters carried out evenly at pre-existing trails and roads during other field activities. To avoid biased sampling of the some species baits were not used.

Camera traps were set at 20 stations spaced at least $500 \mathrm{~m}$ among them, covering an area of ca. 1,400 ha. Stations were placed at pre-existing trails and abandoned dirty roads (2 to 8 $\mathrm{m}$ width), which are periodically managed to keep them open. 
Table 1. Medium and large-sized mammals of the Reserva Ecológica de Guapiaçú, Cachoeiras de Macacu, RJ. Type of record: Ct $=$ Camera trap; $\mathrm{Fp}=$ Footprints; $\mathrm{Bw}=$ Burrow $; \mathrm{Fs}=$ Feeding signs $; \mathrm{Cr}=$ Carcass; $\mathrm{Vi}=$ Visualization; $\mathrm{Vo}=$ Vocalization $; \mathrm{Tm}=\mathrm{Territorial}$ marks; $\mathrm{F}=\mathrm{Faeces} ; \mathrm{H}=$ Hair. Status of Threat: PT = presumably threatened; LC = least concern; NT = near threatened; VU = vulnerable; $\mathrm{EN}=$ endangered; $\mathrm{CE}=$ critically endangered. Species nomenclature followed Paglia et al. (2012).

\begin{tabular}{|c|c|c|c|c|c|}
\hline \multirow{2}{*}{$\begin{array}{l}\text { TAXA } \\
\text { (Order/Family/Species) }\end{array}$} & \multirow[t]{2}{*}{ Common Name } & \multirow[t]{2}{*}{ Type of record } & \multicolumn{3}{|c|}{ Degree of threat } \\
\hline & & & RJ & BR & IUCN \\
\hline \multicolumn{6}{|l|}{ Didelphimorphia } \\
\hline \multicolumn{6}{|l|}{ Didelphidae } \\
\hline Didelphis aurita (Wied-Newied, 1826) & Big-eared opossum & $\mathrm{Ct}$ & - & - & LC \\
\hline \multicolumn{6}{|l|}{ Cingulata } \\
\hline \multicolumn{6}{|l|}{ Dasypodidae } \\
\hline Dasypus novemcinctus Linnaeus, 1758 & Nine-banded armadillo & $\mathrm{Ct}, \mathrm{Fp}, \mathrm{Bw}, \mathrm{Fs}, \mathrm{Cr}$ & - & - & $\mathrm{LC}$ \\
\hline Cabassous tatouay (Desmarest, 1804) & Greater naked-tailed armadillo & $\mathrm{Ct}, \mathrm{Fp}, \mathrm{Bw}$ & PT & - & $\mathrm{LC}$ \\
\hline Euphractus sexcinctus (Linnaeus, 1758) & Six-banded armadillo & $\mathrm{Ct}, \mathrm{Bw}, \mathrm{Fs}$ & - & - & $\mathrm{LC}$ \\
\hline \multicolumn{6}{|l|}{ Bradypodidae } \\
\hline Bradypus variegatus Schinz, 1825 & Brown-throated sloth & $\mathrm{Vi}$ & - & - & $\mathrm{LC}$ \\
\hline \multicolumn{6}{|l|}{ Myrmecophagidae } \\
\hline Tamandua tetradactyla (Linnaeus, 1758) & Southern tamandua & $\mathrm{Cr}$ & - & - & $\mathrm{LC}$ \\
\hline \multicolumn{6}{|l|}{ Primata } \\
\hline \multicolumn{6}{|l|}{ Atelidae } \\
\hline \multicolumn{6}{|l|}{ Brachyteles arachnoides É. Geoffroy, } \\
\hline 1806 & Southern muriqui & $\mathrm{Vi}$ & $\mathrm{CE}$ & $\mathrm{EN}$ & $\mathrm{EN}$ \\
\hline \multicolumn{6}{|l|}{ Cebidae } \\
\hline Sapajus nigritus (Goldfuss, 1809) & Black capuchin & Vi & - & - & NT \\
\hline \multicolumn{6}{|l|}{ Carnivora } \\
\hline \multicolumn{6}{|l|}{ Canidae } \\
\hline Cerdocyon thous (Linnaeus, 1766) & Crab-eating fox & $\mathrm{Ct}, \mathrm{Fp}$ & - & - & $\mathrm{LC}$ \\
\hline \multicolumn{6}{|l|}{ Procyonidae } \\
\hline Nasua nasua (Linnaeus, 1766) & South american coati & $\mathrm{Ct}, \mathrm{Vi}, \mathrm{Tm}$ & - & - & $\mathrm{LC}$ \\
\hline Procyon cancrivorus (G.Curvier, 1798) & Crab-eating raccoon & $\mathrm{Fp}$ & - & - & $\mathrm{LC}$ \\
\hline \multicolumn{6}{|l|}{ Mustelidae } \\
\hline Eira barbara (Linnaeus, 1758) & Tayra & $\mathrm{Ct}, \mathrm{Fp}$ & PT & - & $\mathrm{LC}$ \\
\hline Lontra longicaudis (Olfers, 1818) & Neotropical otter & Fs & - & - & $\mathrm{LC}$ \\
\hline Galictis cuja (Molina, 1782) & Lesser grison & $\mathrm{Fp}$ & - & - & $\mathrm{LC}$ \\
\hline \multicolumn{6}{|l|}{ Felidae } \\
\hline Leopardus pardalis (Linnaeus, 1758) & Ocelot & $\mathrm{Ct}$ & VU & VU & $\mathrm{LC}$ \\
\hline Puma concolor (Linnaeus, 1771) & Cougar & $\mathrm{Ct}, \mathrm{Fp}, \mathrm{Tm}, \mathrm{F}$ & VU & VU & $\mathrm{LC}$ \\
\hline \multicolumn{6}{|l|}{ Artiodactyla } \\
\hline \multicolumn{6}{|l|}{ Tayassuidae } \\
\hline Pecari tajacu (Linneaus, 1758) & Collared peccary & $\mathrm{Ct}, \mathrm{Fp}, \mathrm{Fs}$ & VU & - & $\mathrm{LC}$ \\
\hline \multicolumn{6}{|l|}{ Rodentia } \\
\hline \multicolumn{6}{|l|}{ Erethizontidae } \\
\hline Coendou insidiosus (Lichtenstein, 1818) & Bahia porcupine & $\mathrm{H}$ & PT & - & $\mathrm{LC}$ \\
\hline Cuniculidae & & & & & \\
\hline Cuniculus paca (Linnaeus, 1766) & Lowland paca & $\mathrm{Ct}, \mathrm{Fp}, \mathrm{Fs}$ & VU & - & $\mathrm{LC}$ \\
\hline Dasyproctidae & & & & & \\
\hline Dasyprocta leporina (Linnaeus, 1758) & Red-rumped agouti & $\mathrm{Ct}, \mathrm{Fp}, \mathrm{Fs}$ & - & - & $\mathrm{LC}$ \\
\hline Lagomorpha & & & & & \\
\hline Leporidae & & & & & \\
\hline Sylvilagus brasiliensis (Linnaeus, 1758) & Tapiti & Vi & - & - & $\mathrm{LC}$ \\
\hline
\end{tabular}

Even in the wider roads the canopy is closed on most points. Each station received a digital camera trap (Tigrinus $6.0 \mathrm{D}$ or Bushnell Trophicam) for $7.8 \pm 1.9$ days (mean \pm sd) at each month. Traps were active during $24 \mathrm{~h}_{\text {.day }}{ }^{-1}$ with an interval of 1 min between shots. Each picture was considered a record of occurrence; for a same species independent records where those who had at least an hour of interval among each other (Di
Bitetti et al. 2006, Tobler et al. 2008, Goulart et al. 2009, Espartosa et al. 2011).

Sign surveys were carried out at the same trails and roads were the camera traps were located. Each trail was surveyed once a month, during the day, with a constant velocity of 1.5 $\mathrm{Km} / \mathrm{h}$. Recent species signs such as footprints, burrows, feeding signs, carcass, territorial marks (scratch or stripped trees), 


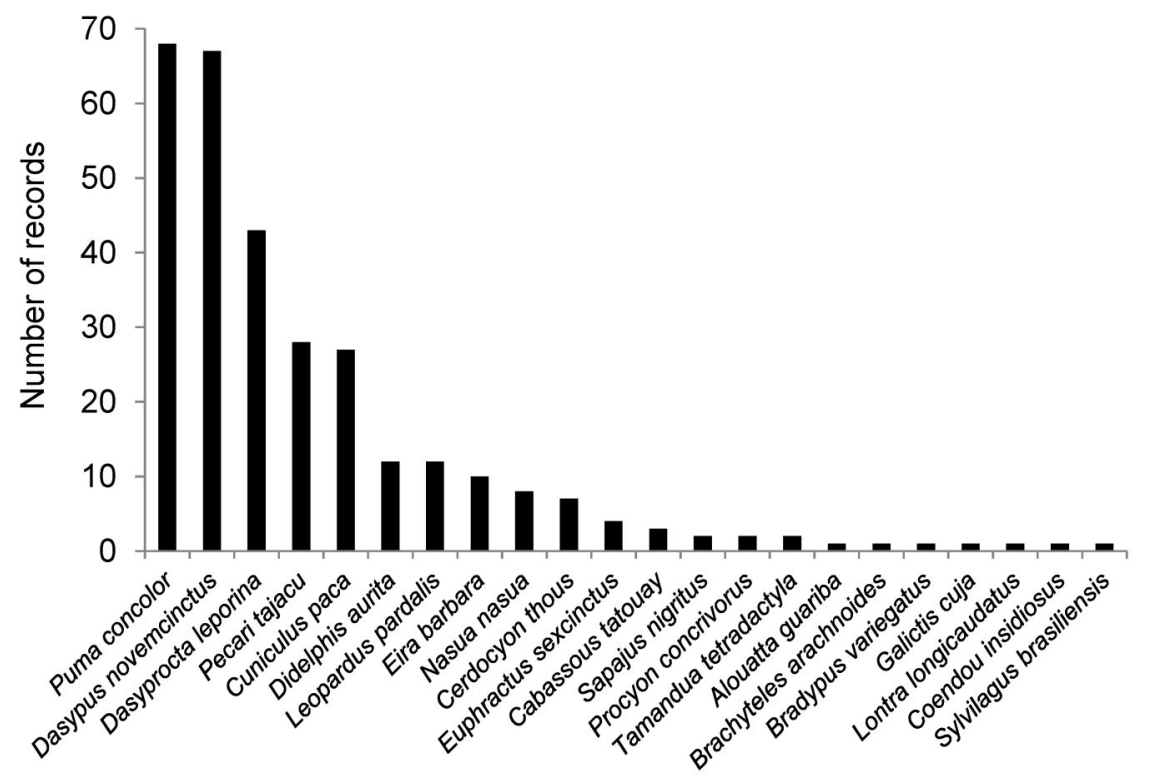

Figure 1 Number of independent records for the 22 species of medium and large-sized mammals recorded by camera traps, sign surveys and visual encounters at the Reserva Ecológica de Guapiaçú (REGUA), Cachoeiras Macacu, Rio de Janeiro.

vocalization and feces, were identified and georeferenced with a GPS. Footprints were identified based on authors knowledge and field guides (Emmons 1997, Becker and Dalponte 1999, Borges and Tomás 2008). For a same species records obtained within a same sample event were considered independent only when spaced at least $500 \mathrm{~m}$ among them.

Considering the independence of visual encounters, different observations of individuals or social groups of a same species in a given trail in the same day were considered as a unique record.

\section{Data analyses}

Sampling effort was evaluated using a species accumulation curve (Magurran 2004) with 1000 simulations; the curve was based on sampling events, considering each month as a sample. Expected richness was obtained through the nonparametric estimator Jackknife 2. This estimator is suitable for the analysis

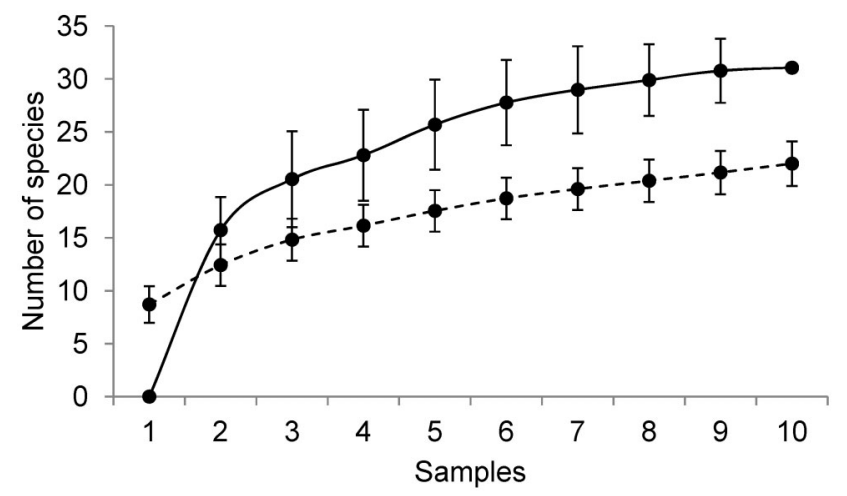

Figure 2 Species accumulation curve (dashed line) and expected richness (solid line) - obtained from the nonparametric estimator Jackknife 2 - to medium and large-sized mammals of the Reserva Ecológica de Guapiaçú, Cachoeiras de Macacu, RJ. Data obtained by camera traps, sign surveys and visual encounters. The bars indicate the standard deviation of each mean value. of communities with low evenness among species (Brose et al. 2003), which is the case of the studied group, and had a good performance in a study carried out with these mammals in the Amazon (Tobler et al. 2008). All the analyses were carried out using EstimateS 8.2.2 (Colwell 2006).

For each species we recorded the degree of threat using Bergallo et al. (2000) for the state of Rio de Janeiro, Chiarello et al. (2008) for the Brazil and the International Union for Conservation of Nature (IUCN 2012) for globally threatened species.

\section{Results}

Considering all the methods used and an effort of 1589 cameras-days and $120 \mathrm{~km}$ of transects, we obtained 302 independent records from 22 species, belonging to eight orders and 15 families of medium and large-sized mammals (Table 1). Twelve species were detected using camera traps, 16 with the sign surveys and five were visual encounters. Only one species (Nasua nasua) was detected by the three methods. Camera traps and transects recorded 10 species in common. Two species were exclusively detected by camera traps, six in the sign surveys and four by visual encounters (Table 1).

Among the species recorded, eight were to order Carnivora $(36.4 \%)$, three Cingulata $(13.6 \%)$, Primates $(13.6 \%)$ and Rodentia (13.6\%), and two were Pilosa (9.1\%). One species of family Didelphidae (4.5\%), Tayassuidae (4.5\%) and Leporidae $(4.5 \%)$ were also registered (Table 1$)$. Besides that, other two species of native mammals were observed; the brown-foureyed-opossum Metachirus nudicaudatus (Desmarest, 1817) and the Ingram's squirrel Guerlinguetus ingrami (Thomas, 1906). In addition, the exotics Callitrix jacchus (Linnaeus, 1758) and Canis lupus familiaris (Linnaeus, 1758) (two individuals) were also recorded.

Considering all the types of records, the species with the higher number of observations were the cougar Puma concolor and the nine-banded-armadillo Dasypus novemcinctus (Figure 1). 
Mammals of REGUA, RJ

Table 2 Inventories of medium and large-sized mammals in dense Atlantic Rainforest and their respective areas of study, richness, sampling efforts and monitoring methods. LT = linear transect; VI = visualization; $\mathrm{SS}=$ sign surveys; $\mathrm{CT}=$ camera traps; $\mathrm{IN}=$ interviews; $\mathrm{SP}=$ sand plot.

\begin{tabular}{|c|c|c|c|c|c|}
\hline State and Local & $\begin{array}{l}\text { Area } \\
\text { (ha) }\end{array}$ & Richness & $\begin{array}{l}\text { Sampling effort } \\
\text { (months) }\end{array}$ & Methods & Reference \\
\hline Rio de Janeiro & & & & $\mathrm{CT}$ & \\
\hline Reserva Ecológica de Guapiaçú & 7300 & 22 & 10 & SS & This study \\
\hline (REGUA) & & & & $\begin{array}{l}\text { VI } \\
\text { LT }\end{array}$ & \\
\hline $\begin{array}{l}\text { Alagoas } \\
\text { Usina Serra Grande }\end{array}$ & 8000 & 22 & 6 & $\begin{array}{l}\text { VI } \\
\text { SS } \\
\text { CT } \\
\text { IN }\end{array}$ & Fernandes 2003 \\
\hline $\begin{array}{l}\text { Rio de Janeiro } \\
\text { Parque Nacional da Serra dos Órgãos }\end{array}$ & 11800 & 34 & 7 & $\begin{array}{l}\text { LT } \\
\text { VI } \\
\text { SS } \\
\text { CT } \\
\text { IN }\end{array}$ & Cunha 2004 \\
\hline $\begin{array}{l}\text { Espírito Santo } \\
\text { Anchieta }\end{array}$ & 390 & 11 & 24 & VI & Passamani et al. 2005 \\
\hline $\begin{array}{l}\text { São Paulo } \\
\text { Reserva Florestal Morro Grande }\end{array}$ & 10870 & 14 & 5 & $\begin{array}{l}\text { SS } \\
\text { SP } \\
\text { LT }\end{array}$ & $\begin{array}{l}\text { Negrão \& Valladares- } \\
\text { Pádua } 2006\end{array}$ \\
\hline $\begin{array}{l}\text { Rio de Janeiro } \\
\text { Parque Estadual do Desengano }\end{array}$ & 22400 & 22 & 1 & $\begin{array}{l}\text { VI } \\
\text { SS } \\
\text { CT }\end{array}$ & Modesto et al. 2008b \\
\hline $\begin{array}{l}\text { Santa Catarina } \\
\text { Reserva Ecológica Caraguatá }\end{array}$ & 4200 & 16 & 17 & $\mathrm{CT}$ & Goulart et al. 2009 \\
\hline $\begin{array}{l}\text { Santa Catarina } \\
\text { Parque Estadual da Serra do Tabuleiro }\end{array}$ & 5000 & 13 & 17 & $\mathrm{CT}$ & Goulart et al. 2009 \\
\hline $\begin{array}{l}\text { Rio de Janeiro } \\
\text { Parque Nacional da Serra da Bocaina }\end{array}$ & 104000 & 18 & 2 & $\begin{array}{l}\text { LT } \\
\text { CT }\end{array}$ & Delciellos et al. 2012 \\
\hline $\begin{array}{l}\text { Rio de Janeiro } \\
\text { Parque Estadual da Ilha Grande }\end{array}$ & 14572 & 11 & 15 & $\mathrm{CT}$ & Lessa, 2011 \\
\hline
\end{tabular}

Seven species $(31.8 \%)$ have only one record (Alouatta guariba, Brachyteles arachnoides, Bradypus variegatus, Galictis cuja, Lontra longicaudatus, Coendou insidiosus and Sylvilagus brasiliensis), obtained through the signs surveys or visual encounters.

The accumulation curve did not reaches an asymptote and the expected richness was 31.1 species (Figure 2).

Considering the degree of threat, five species $(22.7 \%)$ were present in the list of the threatened fauna of the Rio de Janeiro state, while three $(13.6 \%)$ are in risk at Brazil and one $(4.5 \%)$, the Southern muriqui Brachyteles arachnoides, is globally threaten (Table 1).

The species richness found at REGUA was comparable to the registered in other areas harboring the Rain Atlantic Forest, including higher protected areas (Table 2).

\section{Discussion}

Besides the 22 species found in this study, the jaguarundi Puma yagouaroundi (É. Geoffroy, 1803), the margay Leopardus wiedii (Schinz, 1821) and the capybara Hydrochoerus hydrochaeris (Linnaeus, 1766) were also previously detected at REGUA (Pimentel 2005, Rocha et al. 2005). Summing these three species, the area harbor $39 \%$ of the Atlantic Forest medium and large-sized mammal species and $75.7 \%$ of those from Rio de Janeiro state (Rocha et al. 2004).

A failure in the detection of the two feline species mentioned above could be due to two non-excludent reasons, (1) their naturally low population densities (Lyra-Jorge et al. 2008, Almeida et al. 2013), and (2) the high frequency of Puma concolor and Leopardus pardalis in several trails, whose presence has been negatively related to the occurrence of these species (Oliveira et al. 2010, Oliveira 2011, Oliveira-Santos et al. 2012). In addition, for $L$. wiedii, trail characteristics - which were more open, wide and managed than the preferred by the species - could have contributed to this result (Goulart et al. 2009). For H. hydrochaeris the absence of favorable habitats in the trails - as swampy areas - could explain why this species was not detected in this study (Ferraz et al. 2006).

The existence of non-detected species and the higher number of species registered only once $(31.8 \%)$ can be responsible to the non-establishment of the rarefaction curve. These data suggest that these species are rare in the studied area. However, this result could also be due to sampling problems. The use of camera-traps outside the trails and in other habitats (in the canopy, closer to water courses, for example), and night transects in future studies are necessary to clarify this (Harmsen et al. 2010, Melo et al. 2012). 
The observed richness (22 species) represented $70.8 \%$ of the estimated one ( 31.1 species). As the number of species known to the region is 33 (Rocha et al 2004), the use of Jacknife 2 seems to have been adequate to the studied community, corroborating the results found by other authors (Brose et al. 2003, Tobler et al. 2008).

The species with the higher number of records were $P$. concolor and D. novemcinctus. Both species are habitat generalists, occurring both in preserved and anthropized areas (Dickson et al. 2005, Andrade-Nuñez \& Aide 2010, Mazzoli 2010, Canale et al. 2012). The large home range sizes of $P$. concolor (100-220 $\mathrm{Km}^{2}$, Mazzoli 2010) and the difficulty of differentiate individuals (Oliveira-Santos et al. 2010), however, can have contributed to their elevated number of records. Considering $D$. novemcinctus, the foraging behavior can have inflate the number of records as a single individual moves long distances leaving several marks (Neck 1976, Mcbee \& Backer 1982).

Habitat restricted species, that occur preferentially in preserved areas were well represented at REGUA. Among them are Pecari tajacu, Cuniculus paca and L. pardalis that are classified as vulnerable in the state and national red lists (Table 1). The first two are game species (Peres 1996, Cullen et al. 2001) that can maintain viable populations in the area due to the protection actions carried out by the owners and their employees.

Didelphis aurita, which is considered an indicator of disturbed habitats (Bergallo 1994), was less abundant here than in others studies (e.g. Gaspar 2005, Negrão \& ValladaresPádua 2006, Srbek-Araújo \& Chiarello 2007). This result enhances the degree of forest conservation, as this species is generally more abundant is areas where top predators are absent (Fonseca \& Robinson 1990).

The absence of the deer species (Mazama Rafinesque, 1817), white-lipped peccary (Tayassu pecari Link, 1795) and tapir (Tapirus terrestris Linnaeus, 1758) were the most apparent; in the last 10 years species were not detected in the area. For $T$. pecari there is an anecdotal observation by an employee recorded over 50 years, when according to him whole herds were hunted. For Mazama spp. and T. terrestris, the last records where those carried out by naturalists that visited the region in the century XIX (Miller et al. 2006). Habitat fragmentation and principally over hunting must have contributed to the local extinction of these species at the REGUA, as found in other Atlantic Forest regions (e.g. Chiarello 2000, Canale et al. 2013).

The fact that the number of medium and large-sized mammals species found at REGUA was comparable inclusive to large protected areas could be due to the formed continuum with the Parque Estadual dos Três Picos. However, the management and protection of the area by its owners is fundamental to maintain the populations of these animals. The creation of private reserves has been an important strategy for biodiversity conservation in Brazil (e.g. Schiavetti et al. 2010, Negrões et al. 2011). At REGUA, as in other private reserves, the surveillance is done generally by locals, mostly former hunters, who know the region well and are able to keep gatherers and hunters away. The number of species, including cinegetic and endangered ones makes REGUA important to the conservation of medium and large-sized mammals in the state and a stocking area to future recolonizations of regions in their surroundings.

\section{Acknowledgements}

We thank to Nicholas and Rachel Locke for authorizing, incentive and supporting this research in your beautiful property. Many thanks for Mr. Levi and Mr. Messias to assist in the fieldwork and Dr. Jorge Bizarro for logistical support. Thanks to Dr. Nílton Cáceres, Dra. Helena Bergallo, Dra. Flávia Rocha, Dr. Diogo Loretto and anonymous reviewers for comments on previous versions of this work. Thanks to the team of Laboratório de Ecologia e Conservação de Florestas (LECF) for fellowship. To the Programa de Pós-Graduação em Ciências Ambientais e Florestais for supporting to the Master's Dissertation of the first author, which this work is part.

\section{References}

AlmeidA, L.B., QUEIROLO, D., BEISIEGEL, B.M. \& OLIVEIRA, T.G. 2013. Avaliação do estado de conservação do gato-mourisco Puma yagouaroundi (É. Geoffroy Saint-Hilaire, 1083) no Brasil. Biodiversidade Brasileira, 3(1), 99-106.

ANDRADE-NÚÑEZ, M.J. \& AIDE, T.M. 2010. Effects of habitat and landscape characteristics on medium and large species richness and composition in northern Uruguay. Zoologia. 27(6): 909-917, http://dx.doi.org/10.1590/S1984-46702010000600012

ASQUITH, N.M., WRIGHT, S.J. \& CLAUSS, M.J. 1997. Does mammal community composition control recruitment in neotropical forests? Evidence from Panama. Ecology. 78(3): 941-946.

ASQUITH, N.M., TERBORGH, J., ARNOLD, A.E. \& RIVEROS, C.M. 1999. The fruits the agouti ate: Hymenaea courbaril seed fate when its disperser is absent. J. Trop. Ecol. 15(2): 229-235, http:// dx.doi.org/10.1017/S0266467499000772

AZEVEDO, A.D. 2012. Estoque de carbono em áreas de recuperação da mata atlântica com diferentes idades na bacia do rio Guapiaçu, Cachoeiras de Macacu, Rio de Janeiro. Dissertação de Mestrado. Instituto de Florestas, Universidade Federal Rural do Rio de Janeiro, Seropédica, RJ.

BANI, L., BAIETTO, M., BOTTONI, L. \& MASSA, R. 2002. The use of focal species in designing habitat network for a lowland area of Lombardy, Italy. Conserv. Biol. 16(3): 826-831, http://dx.doi.org/ 10.1046/j.1523-1739.2002.01082.x

BAREA-AZCÓN, J.M., VIRGÓS, E., BALLESTEROS-DUPERÓN, E.B., MOLEÓN, M. \& CHIROSA, M. 2007. Surveying carnivores at large spatial scales: a comparison of four broad-applied methods. Biodivers. Conserv. 5: 387-404.

BECK, H., SNODGRASS, J.W. \& THEBPANYA, P. 2013. Long-term exclosure of large terrestrial vertebrates: Implications of defaunation for seedling demographics in the Amazon rainforest. Biol. Conserv. 163: 115-121, http://dx.doi.org/10.1016/j.biocon.2013.03.012

BECKER, M. \& DALPONTE, J.C. 1999. Rastros de mamíferos silvestres brasileiros: um guia de campo. Brasília. $2^{\mathrm{a}}$ edição. Editora da Universidade de Brasília e Edições IBAMA, Brasilia.

BERGALLO, H.G. 1994. Ecology of a small mammal community in an Atlantic Forest area in southeastern Brazil. Stud. Neotrop. Fauna E. 29(4): 197-217, http://dx.doi.org/10.1080/01650529409360932

BERGAllO, H.G, ROCHA, C.F.D., ALVES, M.A.S. \& SLUYS, M.V. 2000. A fauna ameaçada de extinção do estado do Rio de Janeiro. Rio de Janeiro: Editora da Universidade do Estado do Rio de Janeiro, Rio de Janeiro.

BODDICKER, M., RODRIGUEZ, J.J. \& AMANZO, J. 2002. Indices for assessment and monitoring of large mammals within an adaptive management framework. Environ. Monit. Assess. 76: 105-123, http://dx.doi.org/10.1023/A:1015225022101

BORGES, P.A.L. \& TOMÁS, W.M. 2008. Guia de rastros e outros vestígios de mamíferos do Pantanal. 1 ed. Embrapa Pantanal, Corumbá.

BROSE, U., MARTINEZ, N.D. \& WILLIAMS, R.J. 2003. Estimating species richness: sensitivity to sample coverage and insensitivity to spatial patterns. Ecology, 84(9): 2364-2377. 
CANAlE, G.R., PERES, C.A., GUIDORIZZI, C.E., GATTO, C.A.F. \& KIERULFF, C.M. 2012. Pervasive defaunation of forest remnants in a tropical biodiversity hotspots. PLOS One, 7(8): 1-9.

CARDILLO, M. \& BROMHAN, L. 2001. Body size and risk of extinction in Australian mammals. Conserv. Biol. 15(5): 1435-1440, http://dx.doi.org/10.1046/j.1523-1739.2001.00286.x

CARVALHO, W.D., ADANIA, C.H. \& ESBÉRARD, C.E.L. 2013. Comparison of two mammalian surveys made with camera traps in southeastern Brazil, focusing the abundance of wild mammals and domestic dogs. Braz. J. Biol. 73(1): 29-36, http://dx.doi.org/ 10.1590/S1519-69842013000100005

CHIARELLO, A.G. 2000. Influência da caça ilegal sobre mamíferos e aves das matas de tabuleiro do norte do estado do Espirito Santo. Bol. Mus. Biol. Mello Leitão 11/12: 229-247.

CHIARELlO, A.G., AGUiAR, L.M.S., CERQUEIRA, R., MELO, F.R., RODRIGUES, F.H.G. \& SILVA, V.M.F. 2008. Mamíferos ameaçados de extinção no Brasil. In: MACHADO, A.B.M., DRUMMOND, G.M. \& PAGLIA, A.P. (ed.) Livro vermelho da fauna brasileira ameaçada de extinção. MMA/Fundação Biodiversitas. 1420p.

COLWELL, R.K. 2006. EstimateS: statistical estimation of species richness and shared species from samples. Version 8. Persistent URL $<$ purl.oclc.org/estimates $>$. (último acesso em 30/11/2012).

CROUZEILleS, R., LORINI, M.L. \& GRELlE, C.E.V. 2010. Deslocamento na matriz para espécies da Mata Atlântica e a dificuldade da construção de perfis ecológicos. Oecol. Aust. 14(4): 872-900, http://dx.doi.org/10.4257/oeco.2010.1404.06

CULLEN, L. JR, BODMER, E.R. \& VALLADARES-PÁDUA, C. 2001. Ecological consequences of hunting in Atlantic forest patches, São Paulo, Brazil. Oryx, 35(2): 137-144.

CULlEN, L. JR, ABREU, K.C., SANA, D.A. \& NAVA, A.F.D. 2005. Jaguars as landscape detectives for the upper Parana River Corridor, Brazil. Natureza \& Conservação, 3: 147-161.

CUNHA, A.A. 2004. Alterações na composição da comunidade e o status de conservação dos mamíferos de médio e grande porte da Serra dos Órgãos. In Ciência e conservação na Serra dos Órgãos (C. Cronemberger \& E.B. Viveiros de Castro, orgs) IBAMA, Brasília, p. 211-224.

DEAN, W. 1996. A ferro e fogo: a história e a devastação da Mata Atlântica brasileira. Companhia das Letras, São Paulo.

DELCIELlOS, A.C., NOVAES, R.L.M., LOGUERCIO, M.F.C., GEISE, L., SANTORI, R.T., SOUZA, R.F., PAPI, B.S., RAICES, D., VIEIRA, N.R., FELIX, S., DETOGNE, N., SILVA, C.C.S., BERGALLO, H.G. \& ROCHA-BARBOSA, O. 2012. Mammals of Serra da Bocaina National Park, state of Rio de Janeiro, southeastern Brazil. Check List, 8(4): 675-692.

Di BITETTI M.S, PAVIOLO, A. \& DE ÂNGELO, C. 2006. Density, habitat use and activity patterns of ocelots (Leopardus pardalis) in the Atlantic Forest of Misiones, Argentina. J. Zool. 270: 153-163.

DICKSON, B.G., JENNESS, J.S. \& BEIER, P. 2005. Influence of vegetation, topography, and roads on cougar movement in southern California. J. Wildlife Manage. 69(1): 264-276, http://dx.doi.org/ 10.2193/0022-541X(2005)069<0264:IOVTAR > 2.0.CO;2

DIRZO, R. \& MIRANDA, A. 1990. Contemporary defaunation and forest structure, function and diversity - A sequel to John Terborgh, Conserv. Biol. 4(4): 444-447.

DONATTI, C.I., GUIMARÃES JR, P.R \& GALETTI, M. 2009. Seed dispersal and predation in the endemic Atlantic Forest palm Astrocaryum aculeatissimum across a gradient of seed disperser abundance. Ecol. Res. 24: 1187-1195, http://dx.doi.org/10.1007/ s11284-009-0601-x

EMMONS, L.H. 1997. Neotropical rainforest mammals: a field guide. $2^{\text {nd }}$ ed. Chicago University of Chicago Press.

ESPARTOSA, K.D., PINOTTI, B.T. \& PARDINI, R. 2011. Performance of camera trapping and track counts for surveying large mammals in rainforest remnants. Biodivers. Conserv. 20: 2815-2829, http://dx.doi.org/10.1007/s10531-011-0110-4
EWERS, R.M. \& DIDHAM, R.K. 2006. Confounding factors in the detection of species responses to habitat fragmentation. Biol. Rev. 81: 117-142, http://dx.doi.org/10.1017/S1464793105006949

FERNANDES, A.C.A. 2003. Censo de mamíferos em alguns fragmentos de Floresta Atlântica no nordeste do Brasil. Dissertação de Mestrado. Universidade Federal de Pernambuco, Recife, Pernambuco.

FERRAZ, K.M.P.M.B., FERRAZ, S.F.B., MOREIRA, J.R., COUTO, H.T.Z. \& VERDADE, L.M. 2006. Capybara (Hydrochoerus hydrochaeris) distribution in agroecosystems: a cross scale habitat analysis. J. Biogeogr. 34: 223-230, http://dx.doi.org/ 10.1111/j.1365-2699.2006.01568.x

FONSECA, G.A.B. \& ROBINSON, J.G. 1990. Forest size and structure: competitive and predatory effects on small mammal communities. Biol. Conserv. 53(4): 265-294, http://dx.doi.org/ 10.1016/0006-3207(90)90097-9

FUNDAÇÃO SOS MATA ATLÂNTICA \& INPE. 2011. Atlas dos remanescentes florestais da Mata Atlântica período 2008-2010. Fundação SOS Mata Atlântica, São Paulo, e INPE, São José dos Campos, , Brasil. 122p.

GAIDET-DRAPIER, N., FRITZ, H., BOURGAREL, M., RENAUD, P.C., POILECOT, P. CHARDONNET, P., COID, C., POULET, D. \& LE BEL, S.. 2006. Cost and efficiency of large mammal census techniques: comparison of methods for a participatory approach in a communal area, Zimbabwe. Biodivers. Conserv. 15: 735-754, http:// dx.doi.org/10.1007/s10531-004-1063-7

GAleTti, M., DONATTI, C.I., PIRES, A.S., GUIMARÃES JR, P.R \& JORDANO, P. 2006. Seed survival and dispersal of endemic Atlantic Forest palm: the combined effects of defaunation and forest fragmentation. Bot. J. Linn. Soc. 151: 141-149, http:// dx.doi.org/10.1111/j.1095-8339.2006.00529.x

GASPAR, D.A. 2005. Comunidade de mamíferos não voadores de um fragmento de Floresta Atlântica semidecídua do município de Campinas, SP. Tese de Doutorado. Universidade Estadual de Campinas, Campinas, São Paulo.

GOULART, F.V.B., CÁCERES, N., GRAIPEL, M.E., TORTATO, M.A., GHIZONI JR, I.R \& OLIVEIRA-SANTOS, L.G.R. 2009. Habitat selection by large mammals in a southern Brazilian Atlantic Forest. Mamm. Biol. 74: 182-190.

HARMSEN, B.J., FOSTER, R.J., SILVER, S.C., OSTRO, L.E.T. \& DONCASTER, C.P. 2010. Differential use of trails by forest mammals and implications for camera-trap studies: a case study from Belize. Biotropica, 42(1): 126-133, http://dx.doi.org/10.1111/ j.1744-7429.2009.00544.x

HARRISON, R.D., TAN, S., PLOTKIN, J.B., SLIK, F, DETTO, M., BRENES, T., ITOH, A. \& DAVIES, S.J. 2013. Consequences of defaunation for a tropical tree community. Ecol. Lett. 16: 687-694, http://dx.doi.org/10.1111/ele.12102

INTITUTO ESTADUAL DO AMBIENTE (INEA). 2013. Parque Estadual dos Três Picos PETP. http://www.inea.rj.gov.br/unidades/ pqtrespicos.asp. (último acesso em 01/2013).

INTERNATIONAL UNION FOR CONCERVATION OF NATURE (IUCN). 2012. IUCN Red List of Threatened Species. Version 2012.2. http://www.iucnredlist.org. (último acesso em 01/ 2013).

JORGE, M.L.S.P., GALETTI, M., RIBEIRO, M.C. \& FERRAZ, K.M.P.M.B. 2013. Mammal defaunation as surrogate of trophic cascades in a biodiversity hotspot. Biol. Conserv. 163: 49-57, http:// dx.doi.org/10.1016/j.biocon.2013.04.018

KARANTH, K.U. \& NICHOLS, J.D. 1998. Estimation of tiger densities in India using photographic captures and recaptures. Ecology, 79(8): 2852-2862.

KEUROGHLIAN, A. \& EATON, D.P. 2009. Removal of palm fruits and ecosystem engineering in palm stands by white-lipped peccaries (Tayassu pecari) and other frugivores in an isolated Atlantic Forest fragment. Biodivers Conserv, 18:1733-1750.

KINNAIRD, M.F., SANDERSON, E.W., O'BIEN, T.G., WIBISONO, H.T. \& WOOLMER, G. 2003. Deforestation trends 
in a tropical landscape and implications for endangered large mammals. Conserv. Biol. 17(1): 245-257, http://dx.doi.org/10.1046/ j.1523-1739.2003.02040.x

KUPREWICZ, E.K. 2013. Mammal abundances and seed traits control the seed dispersal and predation roles of terrestrial mammals in a Costa Rican Forest. Biotropica, 45(3): 333-342.

KURTEN, E.L. 2013. Cascading effects of contemporaneous defaunation on tropical forest communities. Biol. Conserv. 163: 22-32, http://dx.doi.org/10.1016/j.biocon.2013.04.025

LESSA, I.C.M. 2012. Os mamíferos de médio e grande porte e suas respostas à fatores ambientais, físicos e antrópicos, sobre diferentes perspectivas, no Parque Estadual da Ilha Grande - RJ. Dissertação de Mestrado. Universidade Estadual do Rio de Janeiro. Rio de Janeiro.

LIMA, S.L. \& DILL, L.M. 1990. Behavioral decisions made under the risk of predation: a review and prospectus. Can. J. Zoolog. 68: 619640, http://dx.doi.org/10.1139/z90-092

LYRA-JORGE, M.C., CIOCHETI, G. \& PIVELlO, V.R. 2008. Carnivore mammals in a fragmented landscape in northeast of São Paulo state, Brazil. Biodivers. Conserv. 17: 1573-1580, http:// dx.doi.org/10.1007/s10531-008-9366-8

MAGURRAN, A.E. 2004. Measuring biological diversity. 1 ed. $>$ Blackwell Publishing, Oxford, UK.

MAZZOLLI, M. 2010. Mosaics of exotic forest plantations and native forest as habitat of pumas. Environ. Manage. 46: 237-253, http:// dx.doi.org/10.1007/s00267-010-9528-9

MCBEE, K. \& BACKER, R.J. 1982. Dasypus novemcinctus. Mammalian Species, 142: 1-9.

MELO, G.L., SPONCHIADO, J. \& CÁCERES, N.C. 2012. Use of camera-traps in natural trails and shelters for the mammalian survey in the Atlantic Forest. Iheringia Ser. Zool. 102(1): 88-94.

MILLER, D., WARREN, R., MILLER, I.M. \& SEEHAWER, H. 2006. Serra dos Órgãos: sua história e suas orquídeas. 1 ed. Nova Friburgo, RJ, Editora Scart.

MILLER, B., DOLGEBY, B., FOREMAN, D., DEL RÍO, C.M., NOSS, R., PHILLIPS, M., READING, R., SOULÉ, M.E., TERBORGH, J. \& WILLCOX, L. 2001. The importance of large carnivores to healthy ecosystems. Endangered Species Update. 18(5): 202-210.

MITTERMEIER, R.A. 1986. Primate conservation priorities in the Neotropical region. In Primates: The road to self-sustaining populations. (K. Benirschke ed). Springer-Verlag, New York, p. 221-240.

MODESTO, T.C., PESSÔA, F.S., JORDÃO-NOGUEIRA, T., ENRICI, M.C., COSTA, L.M., ATTIAS, N., ALMEIDA, J., RAICES, D.S.L., ALBUQUERQUE, H.G., PEREIRA, B.C., ESBERÁRD, C.E.L. \& BERGALLO, H.G. 2008a. Mammals, Serra da Concórdia, state of Rio de Janeiro, Brazil. Check List, 4(3): 341-348.

MODESTO, T.C., PESSÔA, F.S., ENRICI, M.C., ATTIAS, N., JORDÃO-NOGUEIRA, T., COSTA, L.M., ALMEIDA, J., ALBUQUERQUE, H.G., \& BERGALLO, H.G. 2008b. Mamíferos do Parque Estadual do Desengano, Rio de Janeiro, Brasil. Biota Neotrop. 8(4): 153-159, http://dx.doi.org/10.1590/ S1676-06032008000400015

MYERS, N., MITTERMEIER, R.A., MITTERMEIER, C.G., DA FONSECA, G.A.B \& KENT, J. 2000. Biodiversity hotspots for conservation priorities. Nature, 403(24): 853-858.

NECK, R.W. 1976. Possible adaptive significance of certain aspects of armadillo foraging behavior. Southwestern Naturalist, 21: 242-243, http://dx.doi.org/10.2307/3669965

NEGRÃO, M.F.F. \& VALLADARES-PÁDUA, C. 2006. Registro de mamíferos de maior porte na Reserva Florestal de Morro Grande, São Paulo. Biota Neotrop. 6(2): 1-13, http://dx.doi.org/10.1590/ S1676-06032006000200006

NEGRÕES, N., REVILLA, E., FONSECA, C., SOARES, A.M.V.M., JÁCOMO, A.T.A. \& SILVEIRA, L. 2011. Private forest reserves can aid in preserving the community of medium and large-sized vertebrates in the Amazon arc of deforestation. Biodivers. Conserv. 20(3): 505-518, http://dx.doi.org/10.1007/s10531-010-9961-3
NORTHON-GRIFFITHS, M. 1978. Counting Animals. No. 1 of a series of Handbooks on techniques currently used in African wildlife Ecology. (J.J.R. Grimsdel ed). African Wildlife Foundation, Nairobi.

NOSS, R.F., QUIGLEY, H.B., HORNOCKER, M.G., MERRILL, T. \& PAQUET, P.C. 1996. Conservation biology and carnivore conservation in the Rocky Montains. Conserv. Biol. 10 (4): 949963, http://dx.doi.org/10.1046/j.1523-1739.1996.10040949.x

OLIVEIRA, T.G., TORTATO, M.A., SILVEIRA, L., KASPER, C.B., MAZIM, F.D., LUCHERINI, M., JÁCOMO, A.T., SOARES, J.B.G., ROSANE, V.M. \& SUNQUIST, M. 2010. Ocelot ecology and its effects on the small-felid guild in the lowland neotropics. p. 559-580. In: Macdonald, D.W. \& Loveridge, A.J. (eds.). Biology and conservation of wild felids. Oxford University Press.

OLIVEIRA, T.G. 2011. Ecologia e conservação de pequenos felinos no Brasil e suas implicações para o manejo. Tese de Doutorado, Universidade Federal de Minas Gerais, Minas Gerais, MG.

OLIVEIRA-FILHO, A.T. \& FONTES, M.A.L. 2000 Patterns of floristic differentiation among Atlantic Forests in southeastern Brazil and the influence of climate. Biotropica, 32(4b): 793-810.

OLIVEIRA-SANTOS, L.G.R., ZUCCO, C.A., ANTUNES, P.C., \& CRAWSHAW JR, P.G. 2010. Is it possible to individually identify mammals with no natural markings using camera-traps? A controlled case-study with lowland tapirs. Mamm. Biol. 75(4): 375-378.

OLIVEIRA-SANTOS, L.G.R., GRAIPEL, M.E., TORTATO, M.A., ZUCCO, C.A., CÁCERES, N.C. \& GOULART, F.V.B. 2012. Abundance changes and activity flexibility of the oncilla, Leopardus tigrinus (Carnivora: Felidae), appear to reflect avoidance of conflict. Zoologia, 29(2): 115-120.

PAGLIA, A.P., FONSECA, G.A.B da, RYLANDS, A.B., HERRMANN, G., AGUIAR, L.M.S., CHIARELlO, A.G., LEITE, Y.L.R., COSTA, L.P., SICILIANO, S., KIERULFF, M.C.M., MENDES, S.L., TAVARES, V.da C., MITTERMEIER, R.A. \& PATTON, J.L. 2012. Lista anotada dos mamíferos do Brasil. $2^{\mathrm{a}}$ edição. Occasional Papers in Conservation Biology. No. 6. Conservation International. 76p.

PASSAMANI, M., DALMASCHIO, J. \& LOPES, S.A. 2005. Mamíferos não-voadores em áreas com predomínio de Mata Atlântica da Samarco Mineração S.A., município de Anchieta, Espírito Santo. Biotemas, 18 (1): 135-149.

PEEL, M.C., FINLAYSON, B.L. \& MCMAHON, T.A. 2007. Updated world map of the Koppen-Geiger climate classification. Hydrol. Earth Syst. Sc. 11: 1633-1644, http://dx.doi.org/10.5194/ hess-11-1633-2007

PERES, C.A. 1996. Population status of white-lipped Tayassu pecari and collared peccaries $T$. tajacu in hunted and unhunted Amazonian forests. Biol. Conserv. 77: 115-123, http://dx.doi.org/ 10.1016/0006-3207(96)00010-9

PERES, C.A. 2000. Effects of subsistence hunting on vertebrate community structure in Amazonian Forests. Conserv. Biol. 14(1): 240-253, http://dx.doi.org/10.1046/j.1523-1739.2000.98485.x

PIMENTEL, L.M.S. 2005. Inventário de mamíferos selvagens na Reserva Ecológica de Guapiaçú. Monografia em Medicina Veterinária. Fundação Educacional Serra dos Órgãos, Teresópolis, Rio de Janeiro, RJ.

REDFORD, K.H. 1992. The empty forest. Bioscience, 42: 412-422.

RIBEIRO, M.C., METZGER, A., MARTENSEN, A.C., PONZONI, F.J. \& HIROTA, M.M. 2009. The Brazilian Atlantic Forest: how much is left, and how is the remaining forest distributed? Implications for conservation. Biol. Conserv. 142: 1141-1153, http://dx.doi.org/10.1016/j.biocon.2009.02.021

ROCHA, C.F.D., BERGALlO, H.G., ALVES, M.A.S. \& VAN SLUYS, M. 2005. Inventário de anfíbios, répteis, aves e mamíferos da Mata Atlântica da Reserva Ecológica de Guapiaçú, Cachoeiras de Macacu, no Estado do Rio de Janeiro. Instituto Biomas Relatório de Referência. 
ROCHA, C.F.D., BERGALLO, H.G., POMBAL-JR, J.P., GEISE, L., VAN-SLUYS, M., FERNANDES, R. \& CARAMASCHI, U. 2004. Fauna de anfíbios, répteis e mamíferos do estado do Rio de Janeiro, Sudeste de Brasil. Publi. Avulsas Mus. Nac. 104: 1-24.

SANDERSON, E.W., REDFORD, K.H., VEDDER, A., COPPOLILLO, P.B \& WARD, S.E. 2002a. A conceptual model for conservation planning based on landscape species requirements. Landscape. Urban Plan. 58: 41-56, http://dx.doi.org/10.1016/ S0169-2046(01)00231-6

SANDERSON, E.W., REDFORD, K.H., CHETKIEWICZ, C.B., MEDELLIN, R.A., RABINOWITZ, A.R., ROBINSON, J.G. \& TABER, A.B. 2002b. Planning to save a species: the jaguar as a model. Conserv. Biol. 16(1): 58-72, http://dx.doi.org/10.1046/ j.1523-1739.2002.00352.x

SANTOS-FILHO, M. \& SILVA, M.N. 2002. Uso de habitats por mamíferos em área de Cerrado do Brasil Central: um estudo com armadilhas fotográficas. Rev. Bras. Zoociênc. 4(1): 45-56.

SCHIAVETTI, A., DE OLIVEIRA, H.T, LINS, A.S \& SANTOS, P.S. 2010. Analysis of private natural heritage reserves as a conservation strategy for the biodiversity of the cocoa region of the southern state of Bahia, Brazil. Rev. Árvore. 34(4): 699-711, http:// dx.doi.org/10.1590/S0100-67622010000400015

SILVA, L.D. \& PASSAMANI, M. 2009. Mamíferos de médio e grande porte em fragmentos florestais no município de Lavras, MG. Rev. Bras. Zoociências, 11(2): 137-144.

SINCLAIR, A.R.E., MDUMA, S. \& BRASHARES, J.S. 2003. Patterns of predation in a diverse predator-prey system. Nature. 425: 288-290, http://dx.doi.org/10.1038/nature01934
SOISALO, M.K. \& CAVALCANTI, S.M.C. 2006 Estimating the density of a jaguar population in the Brazilian Pantanal using camera-traps and capture-recapture sampling in combination with GPS radio-telemetry. Biol. Conserv. 129: 487-496, http:// dx.doi.org/10.1016/j.biocon.2005.11.023

SPÍNOLA, C.M. 2008. Influência dos padrões estruturais da paisagem na comunidade de mamíferos terrestres de médio e grande porte na região do Vale do Ribeira, Estado de São Paulo. Dissertação de Mestrado. Universidade de São Paulo.

SRBEK-ARAÚJO, A.C. \& CHIARELlO, A.G. 2007. Armadilhas fotográficas na amostragem de mamíferos: considerações metodológicas e comparação de equipamentos. Rev. Bras. Zool. 24(3): 647-656, http://dx.doi.org/10.1590/S0101-81752007000300016

STONER, K.E., RIBA-HERNÁNDEZ, P., VULINEC, K. \& LAMBERT, J.E. 2007. The role of mammals in creating and modifying seedshadows in tropical forest and some possible consequences of their elimination. Biotropica, 39(3): 316-327.

TERBORGH, J. 1988. The big things that run the world-a sequel to E. O. Wilson. Conserv. Biol. 2(4): 402-403, http://dx.doi.org/10.1111/ j.1523-1739.1988.tb00207.x

TOBLER, M.W., CARRILlO-PERCASTEGUI, S.E., LEITE PITMAN, R, MARES, R \& POWELL, G. 2008. An evaluation of camera traps for inventorying large- and medium-sized terrestrial rainforest mammals. Anim. Conserv. 11: 169-178, http:// dx.doi.org/10.1111/j.1469-1795.2008.00169.x

TRAVASSOS, L. 2011. Impacto da sobrecaça em populações de mamíferos e suas interações ecológicas nas florestas neotropicais. Oecol. Aust. 15(2): 380-411, http://dx.doi.org/10.4257/oeco.2011.1502.14

Received 13/05/2014 Revised 22/05/2014 Accepted 01/09/2014 